\title{
Concurrent Presence of Cystic Clear Cell Carcinoma Posing as a Simple Cyst in a Kidney with Primary Papillary Carcinoma
}

\author{
Kaveh Homayoon $^{1^{*}}$, Dave Harikrishna ${ }^{2}$ \\ ${ }^{1}$ Division of Urology, Department of Surgery, Maricopa Medical Center, Phoenix, USA \\ ${ }^{2}$ Department of Pathology, Maricopa Medical Center, Phoenix, USA \\ Email: *khomayoon@hotmail.com
}

Received January 19, 2012; revised February 15, 2012; accepted February 27, 2012

\begin{abstract}
We report a case with a primary papillary RCC with concurrent presence of a separate occult cystic carcinoma posing as a simple cyst on preoperative imaging studies.
\end{abstract}

Keywords: Kidney Cancer; Renal Cyst; Nephrectomy

\section{Introduction}

Simultaneous presence of multiple foci of renal cell cancer (RCC) with different histologic types within the same kidney is not common. Presence of multifocal renal lesions poses a challenge in surgical management during nephron sparing procedures for urologists.

We report a case with a primary papillary RCC with concurrent presence of a separate occult cystic carcinoma posing as a simple cyst on preoperative imaging studies.

\section{Case}

The patient is a 57 year old female with right upper quadrant abdominal pain who was diagnosed with an upper pole renal mass by computerized tomography (CT) scan. She had no other co morbidities beside type II diabetes and there was no family history of renal cancer or von Hipple Lindaue disease.

\section{Imaging studies}

CT: There was a $7 \times 4.8 \times 6.8 \mathrm{~cm}$ well circumscribed enhancing mass in the upper pole of right kidney. A separate $1.5 \times 2.2 \mathrm{~cm}$ cyst was present in the posterior lower pole of the same kidney, defined as grade one cyst according to Bosniak classification consistent with simple cyst (Figure 1).

MRI: Right upper pole mass on T1, multiphasic and T2 images, consistent with RCC and a lower pole cyst was diagnosed as a simple cyst (Figure 2).

She underwent radical nephrectomy upon her request,

${ }^{*}$ Corresponding author.

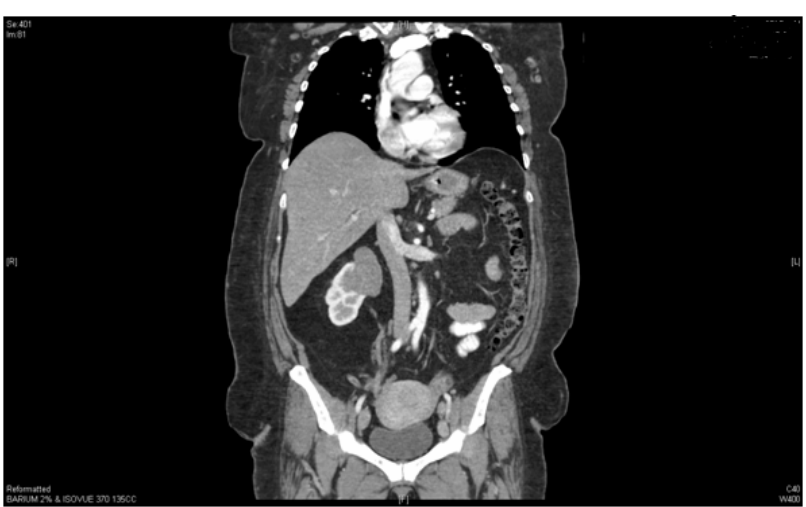

(a)

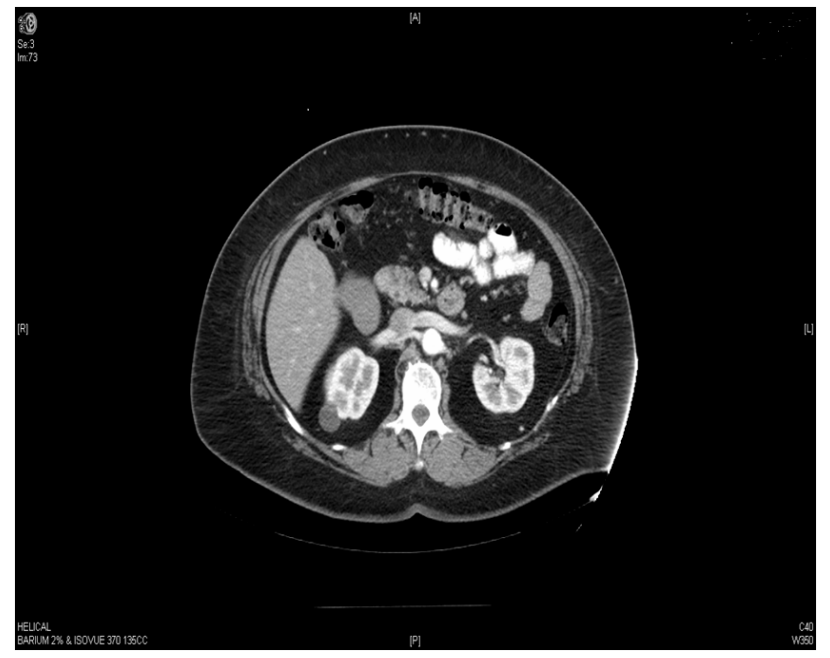

(b)

Figure 1. (a) Upper pole renal mass; (b) Concurrent simple cyst in lower pole. 
though she was offered partial nephrectomy, and was discharged uneventfully few days later.

\section{Pathology}

Microscopic examination of upper pole mass was consistent with papillary RCC. CK7, vimentin and EMA (epithelial membrane antigen) immune staining were strongly positive. CD10 was negative, Ki 67 positive less than $10 \%$ and P53 was positive less than 5\% (Figure 3 ).

Microscopic examination of the lower pole renal cyst revealed cystic clear cell carcinoma with positive immuneperoxidase stain for EMA and vimentin (Figure 4).

\section{Discussion}

There have been many reports for presence of synchronous multifocal RCC in a single kidney [1,2]. Majority of multifocal renal cancers have a similar cell origin and histopathology. In one report $74 \%$ of satellite lesions had similar pathology with the primary RCC [1].

Simultaneous presence of multiple renal cancers with

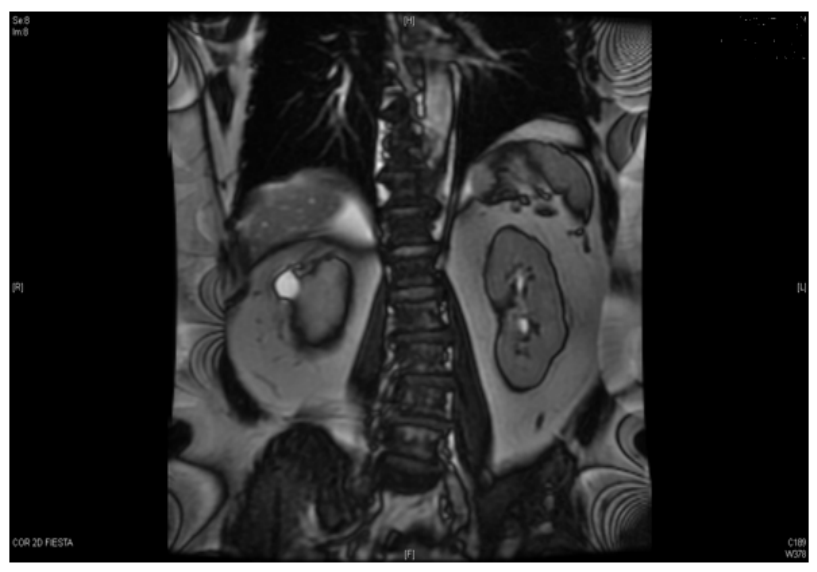

Figure 2. MRI: concurrent simple cystin lower pole.

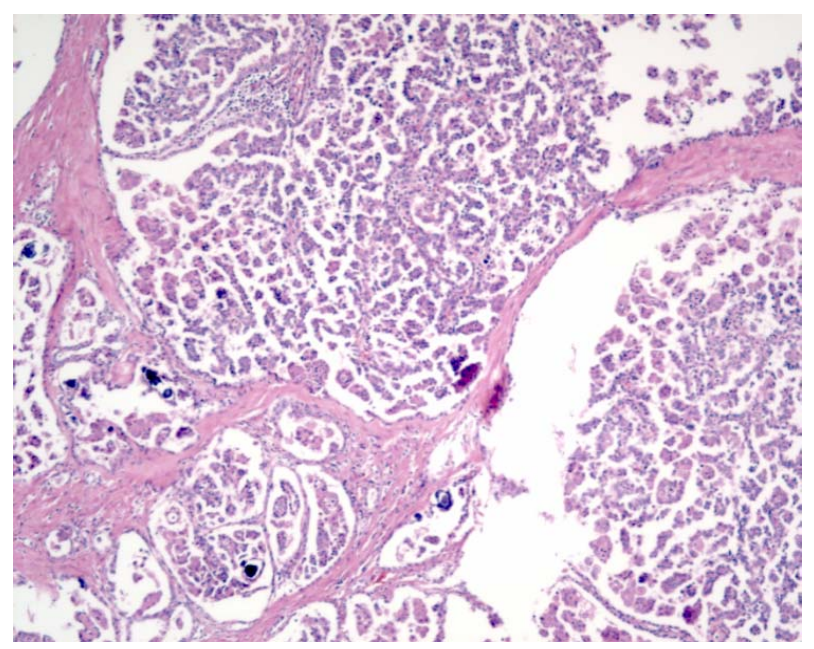

Figure 3. Papillary cell carcinoma $(\times 100)$.

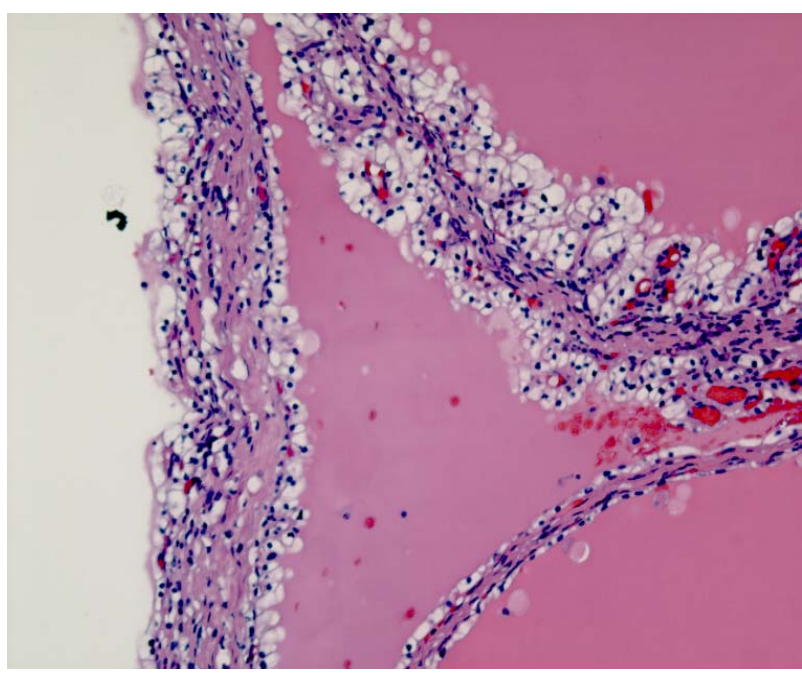

Figure 4. Concurrent cystic renal cancer $(\times 100)$.

different histopathology is being reported increasingly. In one study RCC was reported to coexist with oncocytoma in $7 \%-22 \%$ of the cases [3]. Other studies have reported association of RCC with angiomyolipoma, capsular leiomyoma, and hematological malignancies [4,5]. The two types of cancer present either as a hybrid in the same mass or independently as a satellite lesion in the same kidney.

Many factors are attributed to a potential for development of multifocality in a renal caner. Primary tumor stage is the most significant factor with the incidence signifycantly increases with stage pT3 RCC [6,7].

Papillary type of RCC is associated with a higher rate of multifocality compared to other types [1,2]. The frequency of multifocality in one study was $11 \%$ for papillary RCC and $2 \%$ for clear cell and chromophobe RCC [8]. Positive lymph nodes, von Hipple Lindau disease and Birt Hogg Dube syndrome are other factors associated with higher probability of multifocal RCC $[9,10]$.

Raz et al. in a retrospective study have examined the prevalence of malignancy in satellite renal lesions. In their study, 8 out of 114 renal units with primary Clear cell RCC had satellite malignant lesions in the same kidney mostly of cystic clear cell RCC [11]. To our knowledge this is the first reported case of primary papillary RCC with concurrent secondary cystic clear cell renal carcinoma.

The risk of local recurrence following partial nephrectomy for a localized small (less than $4 \mathrm{~cm}$ ) RCC is $4 \%$ $6 \%[12,13]$. However, multifocality of non-familial types of RCC has not been reported to adversely affect prognosis or survival in patients following partial nephrectomyin only one study [11].

In our opinion, it seems prudent that any secondary lesion identified in the same kidney be evaluated thoroughly to minimize the chance of leaving a malignancy behind after a nephron sparing procedure. 


\section{REFERENCES}

[1] L. Richstone, D. S. Scherer, V. R. Reuter, M. E. Snyder, F. Rabbinic, M. W. Kaftan and P. Russo, "Multifocal Renal Cortical Tumors: Frequency, Associated Clinic Pathological Features and Impact on Survival," Journal of Urology, Vol. 171, No. 2, 2004, pp. 615-620.

[2] E. Mikael, M. Konichezky, D. Engelstein and C. Servadio, "Incidental Small Renal Tumors Accompanying Clinically Overt Renal Cell Carcinoma," Journal of Urology, Vol. 140, No. 1, 1988, pp. 22-24.

[3] M. R. Licht, A. C. Novick, R. R. Tubbs, E. A. Klein, H. S. Levin and S. B. Streem, "Renal Oncocytoma: Clinical and Biological Correlates," Journal of Urology, Vol. 140, No. 5, 1993, pp. 1380-1383.

[4] R. E. Jimenez, J. N. Eble, V. E. Reuter, J. I. Epstein, A. L. Folpe, M. de Peralta-Venturina, P. Tamboli, I. D. Ansell, D. J. Grignon, R. H. Young and M. B. Amin, "Concurrent Angiomyolipoma and Renal Cell Neoplasia: A Study of 36 Cases," Modern Pathology, Vol. 14, No. 3, 2001, pp. 157-163. doi:10.1038/modpathol.3880275

[5] A. A. Petrolla and G. T. MacLennan, "Renal Cell Carcinoma and Other Concurrent Renal Neoplasms," Journal of Urology, Vol. 178, No. 5, 2007, p. 2163. doi:10.1016/j.juro.2007.08.069

[6] S. Baltaci, D. Orhan, S. Soyupek, Y. Bedük, O. Tulunay and O. Gögüs, "Influence of Tumor Stage, Size, Grade, Vascular Involvement, Histological Cell Type and Histological Pattern on Multifocality of Renal Cell Carcinoma," Journal of Urology, Vol. 164, No. 1, 2000, pp. 36-39. doi:10.1016/S0022-5347(05)67443-5

[7] S. Y. Sargin, O. Ekmekcioglu, E. Arpali, M. Altinel and B. Voyvoda, "Multifocality Incidence and Accompanying Clinicopathological Factors in Renal Cell Carcinoma," Uro- logy Internationalis, Vol. 82, No. 3, 2009, pp. 324-329. doi:10.1159/000209366

[8] J. C. Cheville, C. M. Lohse, H. Zincke, A. L. Weaver and M. L. Blute, "Comparisons of Outcome and Prognostic Features among Histologic Subtypes of Renal Cell Carcinoma," American Journal of Surgical Pathology, Vol. 27, No. 5, 2003, pp. 612-624. doi:10.1097/00000478-200305000-00005

[9] R. R. Lonser, G. M. Glenn, M. Walther, E. Y. Chew, S. K. Libutti, W. M. Linehan and E. H. Oldfield, "Von HippelLindau Disease," Lancet, Vol. 361, No. 9374, 2003, pp. 2059-2067. doi:10.1016/S0140-6736(03)13643-4

[10] O. Raz, S. Mendlovic, D. Leibovici, A. J. Pantuck, J. Sandbank, A. Sella, A. Lindner and A. Zisman, "The Prevalence of Malignancy in satellite Renal Lesions and Its Surgical Implication during Nephron Sparing Surgery," Journal of Urology, Vol. 178, No. 5, 2007, pp. 1892-1895. doi:10.1016/j.juro.2007.07.009

[11] B. P. Butler, A. C. Novick, D. P. Miller, S. A. Campbell and M. R. Licht, "Management of Small Unilateral Renal Cell Carcinomas: Radical versus Nephron-Sparing Surgery," Urology, Vol. 45, No. 1, 1995, pp. 34-40. doi:10.1016/S0090-4295(95)96306-5

[12] S. E. Lerner, C. A. Hawkins, M. L. Blute, A. Grabner, P. C. Wollan, J. T. Eickholt and H. Zincke, "Disease Outcome in Patients with Low Stage Renal Cell Carcinoma Treated with Nephron Sparing or Radical Surgery," Journal of Urology, Vol. 155, No. 6, 1966, pp. 1868-1873. doi:10.1016/S0022-5347(01)66032-4

[13] E. Mukamel, M. konichezky, D. Engelstein and C. Servadio, "Incidental Small Renal Tumors Accompanying Clinically Overt Renal Cell Carcinoma," Journal of Urology, Vol. 140, No. 1, 1988, pp. 22-24. 